Revista Eletrônica de Direito Processual - REDP.

Rio de Janeiro. Ano 12. Volume 19. Número 2. Maio a Agosto de 2018

Periódico Quadrimestral da Pós-Graduação Stricto Sensu em Direito Processual da UERJ

Patrono: José Carlos Barbosa Moreira (in mem.). ISSN 1982-7636. pp. 118-148 www.redp.uerj.br

\title{
ACORDOS EM LITÍGIOS COLETIVOS: LIMITES E POSSIBILIDADES DO CONSENSO EM DIREITOS TRANSINDIVIDUAIS APÓS O ADVENTO DO CPC/2015 E DA LEI DE MEDIAÇÃ̃ ${ }^{1}$
}

\section{SETTLEMENTS IN BRAZILIAN CIVIL PUBLIC ACTIONS: LIMITS AND POSSIBILITIES OF CONSENSUS AFTER THE 2015 CIVIL PROCEDURE CODE AND THE MEDIATION ACT}

Humberto Dalla Bernardina de Pinho Professor Titular de Direito Processual Civil na UERJ, ESTACIO e IBMEC. Martin-Flynn Global Law Professor na University of Connecticut School of Law. Diretor Acadêmico da Fundação Escola do MP/RJ. Membro do Ministério Público do Estado do Rio de Janeiro. E-mail: humbertodalla@gmail.com

RESUMO: O texto procura demonstrar como a legislação brasileira tem evoluído no caminho para permitir e viabilizar os acordos em questões coletivas. Afastando-se de uma noção de direito público absolutamente indisponível, o legislador brasileiro vem prestigiando a solução consensual de litígios mesmo nas searas pública e coletiva. Tal transição vem sendo instrumentalizada, principalmente, pelo compromisso de ajustamento de conduta e pela mediação pública. Contudo, nesse momento de transição, importante fixar certos limites a fim de não se perder de vista a segurança jurídica.

PALAVRAS-CHAVE: Consenso. Tutela Coletiva. Limites. Litígios.

ABSTRACT: The text seeks to demonstrate how Brazilian legislation has evolved along the way to allowing and making feasible settlements in collective issues. Moving away from a notion of an absolutely unavailable public right, Brazilian lawmaker has prioritized a consensual solution to disputes, even in the public and class sphere. This transition has been materialized, principally, by the undertaking of adjustment of conduct and public

\footnotetext{
${ }^{1}$ Artigo recebido em 08/03/2018 e aprovado em 26/05/2018.
} 
Revista Eletrônica de Direito Processual - REDP.

Rio de Janeiro. Ano 12. Volume 19. Número 2. Maio a Agosto de 2018

Periódico Quadrimestral da Pós-Graduação Stricto Sensu em Direito Processual da UERJ

Patrono: José Carlos Barbosa Moreira (in mem.). ISSN 1982-7636. pp. 118-148 www.redp.uerj.br

mediation. However, at this moment, it is important to set certain limits, so as not to lose sight of legal security and objective parameters to the settlements.

KEY WORDS: Consensus. Collective Protection. Limits. Possibilities.

SUMÁRIO: 1. Considerações iniciais. 2. O compromisso de ajustamento de conduta como forma de acordo em litígios coletivos. 3. O cabimento da mediação envolvendo questões coletivas ou públicas. 4. A possibilidade dos acordos sobre o procedimento da ação coletiva. 5. Um olhar comparativo sobre o instituto do settlement nas class actions do direito norte-americano. 6. Considerações finais. 7. Referências Bibliográficas.

\section{Considerações Iniciais}

Esse estudo ${ }^{2}$ se destina a examinar o instituto do compromisso de ajustamento de conduta, que vem passando por grandes transformações no direito brasileiro, sobretudo a partir do advento da Lei de Mediação e das novas práticas ligadas à colaboração premiada e aos acordos de leniência previstos, respectivamente, nas Leis $\mathrm{n}^{\circ} 12.850 / 2013$ e $12.846 / 2013$.

Nesse sentido, o objetivo principal desse trabalho é examinar os limites objetivos do acordo nas situações que envolvem direitos transindividuais tutelados por meio de ações civis públicas.

O nascimento desse instituto, em particular, e da tutela coletiva, em geral, advém da constatação da inadequação do modelo processual clássico à obtenção da tutela dos direitos de terceira dimensão, pensados sob o prisma da solidariedade.

Nesse contexto, voltado à proteção dos interesses coletivos lato sensu, cuja titularidade não pertence exclusivamente aos legitimados à propositura da ação civil pública, surge o termo ou compromisso de ajustamento de conduta (TAC), como uma ferramenta conciliatória relevante, viabilizadora do acesso à justiça consensual, além de

\footnotetext{
${ }^{2}$ Versão em português do paper apresentado em 25 de janeiro de 2018 no "Faculty Lounge" da University of Connectiut School of Law, durante minhas atividades como Martin-Flynn Global Law Professor. Agradeço ao Diretor Timothy Fisher e aos professores Angel Oquendo e Peter Lindseth pelo convite e pela hospitalidade durante o período das pesquisas e visitas acadêmicas.
} 
Revista Eletrônica de Direito Processual - REDP.

Rio de Janeiro. Ano 12. Volume 19. Número 2. Maio a Agosto de 2018

Periódico Quadrimestral da Pós-Graduação Stricto Sensu em Direito Processual da UERJ

Patrono: José Carlos Barbosa Moreira (in mem.). ISSN 1982-7636. pp. 118-148

www.redp.uerj.br

apta a colaborar para a desobstrução da máquina judiciária por se evitar a propositura da ação coletiva competente ${ }^{3}$.

Note-se que a instituição do TAC leva a diversas discussões sensíveis e atuais: i) anseio de efetivação da tutela coletiva consensual, mitigando-se certos dogmas, como o da indisponibilidade de interesses públicos e de interesses transindividuais; ii) aplicabilidade ou não de todas as saídas apresentadas pela autocomposição na resolução dessa espécie complexa de conflito, que são: transação, reconhecimento jurídico do pedido do autor, desistência da ação ou do pedido e renúncia à pretensão de direito material; e iii) instituição de medidas eficientes que se encontrem harmonizadas com a maior participação possível das partes e de todos os interessados, de modo a se assegurar o controle social das decisões - ou de decisões efetuadas por meio de medidas estruturantes ${ }^{4}$-, além da inafastável observância do princípio da publicidade e da moralidade administrativa.

\section{O compromisso de ajustamento de conduta como forma de acordo em}

\section{litígios coletivos}

Tem sido alvo de amplo debate na doutrina a natureza jurídica do compromisso de ajustamento de conduta, desde sua inserção no $§ 6^{\circ}$ no art. $5^{\circ}$ da Lei da Ação Civil Pública, pelo Código de Defesa do Consumidor. Não é questão meramente teórica, sendo, ao contrário, importante para se mensurar a abrangência objetiva do TAC e, caso seja admitida a negociação em seu bojo, a possibilidade de se identificar os produtos obtidos desta prática.

De toda sorte, o TAC tem sempre caráter facultativo: ou seja, nem o órgão público pode ser obrigado a oferta-lo e nem o investigado pode ser forçado a aceita-lo nos termos propostos. Haverá, sempre, um fator discricionário a ser levado em conta ${ }^{5}$.

De maneira geral, podem ser apontados dois posicionamentos: o primeiro considera o TAC uma transação especial e o segundo o classifica como um ato jurídico atípico, sui generis ${ }^{6}$.

\footnotetext{
${ }^{3}$ PINHO, Humberto Dalla Bernardina de; FARIAS, Bianca Oliveira de. Apontamentos sobre o compromisso de ajustamento de conduta na Lei de Improbidade Administrativa e no Projeto de Lei da Ação Civil Pública. In: Temas de Improbidade Administrativa, Rio de Janeiro: Lumen Juris, 2010, v.1, p. 99.

${ }^{4}$ PINHO, Humberto Dalla Bernardina de. CÔRTES, Victor Augusto Passos Villani. As medidas estruturantes e a efetividade das decisões judiciais no ordenamento jurídico brasileiro. Revista Eletrônica de Direito Processual, v. XIII, jan-jun/2014, pp. 229/258. Disponível em: http://www.epublicacoes.uerj.br/index.php/redp/. Acesso em: agosto 2014.

${ }^{5}$ STJ. REsp 596.764-MG, Rel. Min. Antonio Carlos Ferreira, julgado em 17/5/2012. Informativo STJ no 497.
} 
Revista Eletrônica de Direito Processual - REDP.

Rio de Janeiro. Ano 12. Volume 19. Número 2. Maio a Agosto de 2018

Periódico Quadrimestral da Pós-Graduação Stricto Sensu em Direito Processual da UERJ

Patrono: José Carlos Barbosa Moreira (in mem.). ISSN 1982-7636. pp. 118-148 www.redp.uerj.br

Interessante abordar a pesquisa elaborada por Geisa de Assis Rodrigues? principalmente em relação à ampliação dos limites observados na negociação. A autora considera o TAC um negócio jurídico bilateral, em certa medida conciliatório, mas não se pode dizer que seja transacionável. Para ela, então, é impossível a solução negociada dos direitos transindividuais, embora se utilize o rótulo de "transação".

Isso porque o espectro conciliatório se manifesta quanto aos aspectos adjacentes, ou seja, circunstâncias instrumentais ou periféricas da obrigação, sempre com a observância da proporcionalidade e da razoabilidade, para não se afetar o dever principal. Exemplifica com a possibilidade de os legitimados pactuarem acordos sobre o modo, o tempo ou o lugar do cumprimento da conduta para a reparação do dano coletivo causado.

Entretanto, deve-se notar para uma tendência recente de defesa de uma nova diretriz quanto à negociabilidade dos direitos coletivos. Os posicionamentos rígidos acabam descartados, pois pautados em argumentos genéricos que vêm impedindo a efetividade do TAC no plano prático.

Assim sendo, entendemos que não mais é viável manutenção do dogma onipotente sobre a indisponibilidade absoluta do direito material coletivo, afastando um mínimo de margem negocial necessário para a efetivação da avença. A superação dessa linha de pensamento, então, parece imprescindível para serem atendidos os anseios por um sistema coletivo adequado.

Nesse sentido, para Angel Oquendo ${ }^{8}$ a indisponibilidade deve ser circunscrita apenas à renúncia do direito, até mesmo porque questões acessórias ou novos fatos podem ser discutidos em casos futuros.

\footnotetext{
${ }^{6}$ NERY, Ana Luiza de Andrade. Compromisso de Ajustamento de Conduta. Teoria e Análise de casos práticos. $2^{\mathrm{a}}$ Ed. São Paulo: Revista dos Tribunais, 2012, p. 119.

${ }^{7}$ RODRIGUES, Geisa de Assis. Ação Civil Pública e Termo de Ajustamento de Conduta: teoria e prática, $4^{\mathrm{a}}$ edição, Rio de Janeiro: Forense, 2013, p. 132.

8 “'(...) a settlement may seem to boil down to condoning, for a fee or quick fix, the impingement upon the group right in question. It may appear to run counter to the characterization of such entitlements as inalienable or non-disposable, particularly in Latin America. Upon deeper inspection, however, this inalienability or non-disposability must merely mean that one may not renounce the right at issue or consent to an infringement. The government or any other nominal claimant may only seek vindication, whether by litigating or settling for adequate satisfaction equivalent to the expected adjudicative relief discounted by the costs and risks of litigation. (...) a suitable settlement neither undercuts nor undermines societal entitlements. Instead, it vindicates them. In this scenario, representatives require less time and expense to move the violator to restitute or compensate upon an impingement. Consequently, they may yield some on the total value of the anticipated adjudicative recovery and still come out ahead". OQUENDO, Angel. State Settlements in Vindication of Societal Rights. Original ainda não publicado e cedido pelo autor em Janeiro de 2018, p. 29.
} 
Revista Eletrônica de Direito Processual - REDP.

Rio de Janeiro. Ano 12. Volume 19. Número 2. Maio a Agosto de 2018

Periódico Quadrimestral da Pós-Graduação Stricto Sensu em Direito Processual da UERJ

Patrono: José Carlos Barbosa Moreira (in mem.). ISSN 1982-7636. pp. 118-148 www.redp.uerj.br

Portanto, a experiência demonstra que um grau maior de autonomia aos órgãos públicos para celebrar o TAC levaria uma maior eficácia, sob a condição de serem observados certos parâmetros de controle e limitação.

Como bem refere Carlos Alberto de Salles ${ }^{9}$, a disponibilidade do direito não está relacionada diretamente a direitos patrimoniais de caráter privado.

Segundo Bruno Takahashi ${ }^{10}$, a partir dessas premissas, é possível aferir que o interesse público, por si só, não é indisponível, devendo ser examinado à luz das peculiaridades do caso concreto. Nesse contexto, vem ganhando espaço a tese doutrinária que visualiza, em um juízo de ponderação, a partir do caso concreto, a possibilidade de as partes realizarem concessões recíprocas para chegar à transação.

Conforme sustenta Ana Luiza Nery ${ }^{11}$ o compromisso é um negócio jurídico bilateral no qual se reconhece a finalidade de contrair, modificar ou extinguir direitos. A celebração objetivaria o alcance da melhor alternativa para reparar ou evitar a lesão a um bem de natureza metaindividual.

A partir dessa ideia então, mesmo um legitimado não podendo abrir mão de um direito essencialmente coletivo, não haveria óbice à renúncia de, por exemplo, uma obrigação acessória ou até mesmo principal, se não se referir ao núcleo do dever central.

É certo que a análise sobre a viabilidade da negociação em matéria coletiva, desde que não se renuncie ao direito material coletivo em sua substância, requer aguçada sensibilidade $^{12}$ do órgão público legitimado ${ }^{13}$.

Deve haver a verificação então, em concreto, do princípio da proporcionalidade em todos os seus níveis ou subníveis de aferição - necessidade, adequação e proporcionalidade em sentido estrito - de modo a se escolher a via mais apta para a melhor efetivação possível do direito violado, com a reparação imediata da conduta ilícita ${ }^{14}$.

\footnotetext{
${ }^{9}$ SALLES, Carlos Alberto de. Arbitragem em Contratos Administrativos. Rio de Janeiro: Forense, 2012, p. 294.

${ }^{10}$ TAKAHASHI, Bruno. Desequilíbrio de poder e conciliação, Brasília: Gazeta Jurídica, 2016, p. 61.

${ }^{11}$ NERY, Ana Luiza de Andrade. Compromisso de Ajustamento de Conduta. Teoria e Análise de casos práticos. $2^{\text {a }}$ Ed. São Paulo: Revista dos Tribunais, 2012, p. 119.

${ }^{12}$ STF. RE no 253-885-0/MG, Rel. Min. Ellen Gracie. Publicado no DJ 21.06.02.

${ }^{13}$ STJ. REsp n ${ }^{\circ}$ 299.400/RJ, $2^{\text {a }}$ Turma. Rel. Min. Eliana Calmon, DJ 02.08.2006.

${ }^{14} \mathrm{Na}$ jurisprudência norte-americana, procura-se construiu parâmetros objetivos para a verificação da proporcionalidade. Veja-se, por exemplo, o julgado a seguir: "In determining the fairness, reasonableness, and adequacy of a settlement, the court considers the substantive terms of the settlement compared to the likely result of a trial, as well as the negotiating process itself, examined in light of the experience of counsel, the vigor with which the case was prosecuted, and any coercion or collusion that may have marred the negotiations themselves A court determining whether a proposed settlement of a class action should be
} 
Revista Eletrônica de Direito Processual - REDP.

Rio de Janeiro. Ano 12. Volume 19. Número 2. Maio a Agosto de 2018

Periódico Quadrimestral da Pós-Graduação Stricto Sensu em Direito Processual da UERJ

Patrono: José Carlos Barbosa Moreira (in mem.). ISSN 1982-7636. pp. 118-148

www.redp.uerj.br

A determinação dos limites observados na negociação que versar sobre direitos transindividuais consiste em um outro desafio a ser enfrentado, sobretudo a partir das mudanças anunciadas, conforme se confere adiante.

Quanto às vedações ao conteúdo do TAC, são proscritas determinadas cláusulas ${ }^{15}$ : i) impossibilidade de afastar o acesso dos lesados ao Judiciário, em razão da inevitabilidade da jurisdição, presente no art. $5^{\circ}$, inciso XXXV da Constituição Federal. Assim sendo, não se pode impedir que outro colegitimado firme novo compromisso com objeto mais amplo ou com outra obrigação não inclusa no primeiro ajuste, ou, até mesmo, ajuizar ação civil pública nas respectivas hipóteses de cabimento; e ii) vedação ao enfraquecimento do núcleo do direito material em jogo. Não se pró́be, todavia, transigência quanto à renúncia da obrigação periférica ou de parte inexpressiva da obrigação principal.

Outro ponto que também se deve atentar é o regime excepcional da lei de improbidade administrativa (Lei $\left.\mathrm{n}^{\circ} 8.429 / 1992\right)$ ). O art. 17, $\S 1^{\circ}$ da referida legislação, se interpretado isoladamente, veda a transação, o acordo ou a conciliação nas ações destinadas a se apurar a prática de ato de improbidade praticados por qualquer agente público.

Registre-se que, por outra perspectiva, a Lei de Mediação, no art. 36, § $4^{\circ}$, abre a possibilidade de, "nas hipóteses em que a matéria objeto do litígio esteja sendo discutida em ação de improbidade administrativa ou sobre ela haja decisão do Tribunal de Contas da União, a conciliação de que trata o caput dependerá da anuência expressa do juiz (...)", o que parece jogar novas luzes sobre a discussão.

Em um primeiro momento, a lei de improbidade parece ostentar obstáculo absoluto para a realização do TAC, independentemente da natureza jurídica definida para o compromisso.

approved considers (1) the complexity, expense, and likely duration of the litigation, (2) the probability of the plaintiffs' success on the merits, (3) the stage of the proceedings and the amount of discovery completed, (4) the range of possible recovery, (5) the existence of fraud or collusion behind the settlement, and (6) the experience and opinions of class counsel and class representatives, (7) the substance and amount of opposition to the settlement, (8) the strength of plaintiff's case, (9) the risk of maintaining class action status throughout the trial, (10) the amount offered in settlement, and (11) the presence of a governmental participant". Thomas Smithand Elizabeth Williams. Court approval of class action settlement, 6 Cyc. of Federal Proc. § 23:42 (3d ed.). Access pelo sítio Westlaw em 5 de janeiro de 2018.

15 PINHO, Humberto Dalla Bernardina de. FARIAS, Bianca Oliveira de. Apontamentos sobre o compromisso de ajustamento de conduta na Lei de Improbidade Administrativa e no Projeto de Lei da Ação Civil Pública. In: Temas de Improbidade Administrativa, Rio de Janeiro: Lumen Juris, 2010, p. 116. 
Revista Eletrônica de Direito Processual - REDP.

Rio de Janeiro. Ano 12. Volume 19. Número 2. Maio a Agosto de 2018

Periódico Quadrimestral da Pós-Graduação Stricto Sensu em Direito Processual da UERJ

Patrono: José Carlos Barbosa Moreira (in mem.). ISSN 1982-7636. pp. 118-148 www.redp.uerj.br

A possibilidade da colaboração premiada, prevista na Lei n. 12.850/2013, traz novos paradigmas para a discussão ${ }^{16}$. O dispositivo, de natureza claramente contratual, ${ }^{17}$ favorece coautores, beneficiários ou cúmplices que espontaneamente revelem às autoridades competentes o nome dos mentores e dos principais autores do fato.

Ademais, após o advento da Lei no 12.846/2013 - Lei Anticorrupção -, a permissão de se firmar acordos de leniência (arts. 16 e 17) parece apontar mais claramente à possibilidade de flexibilização da vedação constada do art. $17, \S 1^{\mathrm{o}} 18$.

Como se pode perceber, mesmo em tema tão sensível, os autores ${ }^{19}$ tendem a flexibilizar o conceito de indisponibilidade material do direito, o que vem ao encontro das considerações expostas nesse texto ${ }^{20}$.

Essa tendência, aliás, foi expressamente acolhida pela Resolução n 179/2017 do Conselho Nacional do Ministério Público, que será examinada a seguir.

Nesse sentido, o caput do art. $1^{\circ}$ dessa Resolução estabelece que o TAC é um "instrumento de garantia dos direitos e interesses difusos e coletivos, individuais homogêneos e outros direitos de cuja defesa está incumbido o Ministério Público, com natureza de negócio jurídico que tem por finalidade a adequação da conduta às exigências legais e constitucionais, com eficácia de título executivo extrajudicial a partir da celebração".

A questão mais relevante para o nosso estudo pode ser encontrada no $\S 2^{\circ}$ : "É cabivel o compromisso de ajustamento de conduta nas hipóteses configuradoras de improbidade administrativa, sem prejuízo do ressarcimento ao erário e da aplicação de uma ou algumas das sanções previstas em lei, de acordo com a conduta ou o ato praticado".

\footnotetext{
${ }^{16}$ PINHO. Humberto Dalla Bernardina de. MELLO PORTO, José Roberto Sotero de. Colaboração premiada: um negócio jurídico processual? In Revista Magister de Direito Penal e Processual Penal, vol. 73, Ago/Set 2016, Magister: Porto Alegre, p. 32.

${ }^{17}$ DIDIER JR, Fredie. BOMFIM, Daniela. Colaboração premiada (Lei n. 12.850/2013): natureza jurídica e controle da validade por demanda autônoma - um diálogo com o Direito Processual Civil, https://www.academia.edu/25608182/Colabora\%C3\%A7\%C3\%A3o_premiada_Lei_n._

12.850_2013_natureza_jur\%C3\%ADdica_e_controle_da_validade_por_demanda_aut\%C3\%B4noma_um_di \%C3\%A1logo_com_o_Direito_Processual_Civil, acesso em 10 de julho de 2016, p. 17.

${ }^{18}$ A Lei foi regulamentada pelo Decreto ${ }^{\circ}$ 8.420, de 18 de março de 2015. Texto disponível em http://www.planalto.gov.br/ccivil_03/_Ato2015-2018/2015/Decreto/D8420.htm. Acesso em 15 de junho de 2016.

${ }_{19}$ MARTEL, Letícia de Campos Velho. Direitos fundamentais indisponíveis: limites e padrões do consentimento para a autolimitação do direito à vida. Tese de Doutorado. Uerj, 2010. Disponível em: http://works.bepress.com/leticia_martel/, p. 18.

${ }^{20}$ VENTURI, Elton. Transação de Direitos Indisponíveis? In Revista de Processo, vol. 251, São Paulo: Revista dos Tribunais, jan. / 2016, pp. 391/426.
} 
Revista Eletrônica de Direito Processual - REDP.

Rio de Janeiro. Ano 12. Volume 19. Número 2. Maio a Agosto de 2018

Periódico Quadrimestral da Pós-Graduação Stricto Sensu em Direito Processual da UERJ

Patrono: José Carlos Barbosa Moreira (in mem.). ISSN 1982-7636. pp. 118-148 www.redp.uerj.br

Não custa lembrar que o art. 12 da Lei ${ }^{\circ}$ 8.429/1992, prevê a seguintes sanções para os atos de improbidade, a serem aplicadas cumulativa ou alternadamente: a) perda dos bens ou valores acrescidos ilicitamente ao patrimônio; b) ressarcimento integral do dano; c) perda da função pública; d) suspensão dos direitos políticos de oito a dez anos; e) pagamento de multa civil de até três vezes o valor do acréscimo patrimonial; f) proibição de contratar com o Poder Público ou receber benefícios ou incentivos fiscais pelo prazo de dez anos.

Ademais, o $\S 3^{\circ}$ desse art. $1^{\circ}$ preceitua que a celebração do compromisso não afasta, necessariamente, a eventual responsabilidade administrativa ou penal pelo mesmo fato.

Esse ponto tem especial relevância pois confere maior segurança jurídica ao ajuste. Dessa forma, o compromisso pode excluir ou incluir benefícios nas áreas criminal e administrativa. Contudo, nessa hipótese, algumas cautelas devem ser adotadas, sobretudo para manter a isonomia entre os benefícios concedidos a investigados diversos, bem como para preservar o princípio do promotor natural. Aliás, nessa linha já havia se posicionado o $\mathrm{STJ}^{21}$, mesmo antes da inovação normativa.

Por fim, o $\S 4^{\circ}$ deixa ao critério discricionário do órgão do Ministério Público decidir quanto à necessidade, conveniência e oportunidade de audiências públicas com a participação dos interessados. Nesse ponto específico, parece-nos que a diligência deveria ser sempre necessária, e não apenas facultativa.

É absolutamente fundamental auscultar a sociedade civil organizada e os lesados diretamente pelo ato ilícito. A não realização de pelo menos uma audiência pública pode resultar num isolamento do Ministério Público e, com isso, gerar um acordo que não atenda, da melhor forma, os interesses da sociedade, ou, pior, um acordo que revele solução rápida e consensual, mas que não gere a resolução efetiva e duradoura do problema.

\section{O cabimento da mediação envolvendo questões coletivas ou públicas.}

Além da previsão do TAC na legislação específica e ainda no art. 174, III do CPC combinado com o art. 32, III da Lei de Mediação, é preciso atentar para a possível

\footnotetext{
${ }^{21}$ STJ. HC 187.043-RS, Rel. Min. Maria Thereza de Assis Moura, julgado em 22/3/2011. Informativo STJ n ${ }^{\circ}$
} 211. 
Revista Eletrônica de Direito Processual - REDP.

Rio de Janeiro. Ano 12. Volume 19. Número 2. Maio a Agosto de 2018

Periódico Quadrimestral da Pós-Graduação Stricto Sensu em Direito Processual da UERJ

Patrono: José Carlos Barbosa Moreira (in mem.). ISSN 1982-7636. pp. 118-148 www.redp.uerj.br

realização do acordo por outros legitimados privados, ou seja, sem a participação do Ministério Público, da Defensoria ou mesmo da Advocacia Pública.

Referimo-nos aqui aos legitimados para a propositura da ação civil pública, mas que não podem, ao menos numa interpretação literal, tomar o termo de ajustamento de conduta. É o caso, por exemplo, das associações de classe, confederações e sociedades civis sem fins lucrativos.

Não custa lembrar que o art. $3^{\circ}, \S 2^{\circ}$ da Lei $n^{\circ} 13.140 / 2015$ permite o consenso envolvendo direitos indisponíveis transacionáveis, desde que o acordo seja levado à homologação judicial, com prévia oitiva do MP.

Nesse sentido, poderíamos estender a aplicação desse dispositivo também para os direitos transindividuais e visualizar uma hipótese de acordo em ação civil pública promovida por associação de classe (durante a audiência de conciliação ou de mediação, por exemplo) caso o juiz entenda que o direito é transacionável (art. $334, \S 4^{\circ}$, inciso II do $\mathrm{CPC})$.

$\mathrm{Na}$ verdade, esse acordo poderia ser alcançado mesmo antes da ACP, em procedimento de mediação prévia e extrajudicial.

Caso a ação seja promovida pelas pessoas jurídicas de direito público interno (União, Estados, Municípios e Distrito Federal), temos que lembrar que o art. 32 da Lei de Mediação permite, expressamente, não apenas a mediação (inciso II) como a promoção do TAC (inciso III).

Ademais, o $§ 3^{-0}$ do art. 32 estabelece que havendo consenso entre as partes, o acordo será reduzido a termo e constituirá título executivo extrajudicial, ou seja, prescinde de homologação, o que parece conflitar com os termos do art. $3^{\circ} \S 2^{\circ}$ acima referido, sobretudo em sede de direitos indisponíveis transacionáveis. Contudo, mais adiante voltaremos ao tema.

Nesse sentido, como bem salienta Luciane Moessa de Souza ${ }^{22}$, existem três fundamentos constitucionais para a adoção de métodos consensuais na resolução de conflitos em que se vê envolvido o Poder Público, a saber: a) o princípio do acesso à justiça (art. $5^{\circ}, \mathrm{XXXV}$, da Const. Federal); b) o princípio da eficiência (art. 37, caput); e c) o princípio democrático $\left(\operatorname{art.} 1^{\circ}\right)$.

\footnotetext{
${ }^{22}$ PINHO, Humberto Dalla Bernardina de et alli (org.). O Marco Legal da Mediação no Brasil, Atlas: São Paulo, 2015, p. 211.
} 
Revista Eletrônica de Direito Processual - REDP.

Rio de Janeiro. Ano 12. Volume 19. Número 2. Maio a Agosto de 2018

Periódico Quadrimestral da Pós-Graduação Stricto Sensu em Direito Processual da UERJ

Patrono: José Carlos Barbosa Moreira (in mem.). ISSN 1982-7636. pp. 118-148 www.redp.uerj.br

Por tais razões, prossegue a autora, deve o Poder Público necessariamente disponibilizar métodos de resolução consensual de conflitos para as situações em que estiver litigando com particulares.

E essa tendência vem sendo seguida nas normas que regem as agências reguladoras, como por exemplo a agência nacional de energia elétrica - ANEEL (artigo $3^{\circ}$, V, da Lei 9.427, de 1996), agência nacional de telecomunicações - ANATEL (artigo 19, XVII, da Lei 9.472, de 1996) e agência nacional do petróleo - ANP (artigo 20 da Lei 9.478, de 1997).

\section{A possibilidade dos acordos sobre o procedimento da ação coletiva}

Com efeito, em sua gênese, o direito processual pertence ao ramo do direito público, ou seja, suas normas, como regra, são cogentes e não admitem modificação pelas partes $^{23}$.

No $\mathrm{CPC} / 73$, a ideia de negócio jurídico processual era controvertida ${ }^{24}$. A doutrina ${ }^{25}$ entendia cabível em algumas hipóteses excepcionais, sempre quando houvesse norma expressa autorizativa, e a jurisprudência ${ }^{26}$ caminhava no mesmo sentido. Entretanto, o assunto já era debatido desde a década de $1980^{27}$.

Em seu caminho evolutivo ${ }^{28}$, o direito processual vem incorporando vários dispositivos que prestigiam o princípio da livre manifestação de vontade das partes. A

\footnotetext{
${ }^{23}$ SANTOS, Marina França. Intervenção de Terceiro Negociada: Possibilidade Aberta pelo Novo Código de Processo Civil. Revista de Processo, vol 241/2015, p. 96.

${ }^{24}$ MACÊDO, Lucas Buril de; PEIXOTO, Ravi de Medeiros. Negócio processual acerca da distribuição do ônus da prova. Revista de Processo, vol. 241/2015, p. 463-487, mar/2015,

${ }^{25}$ CUNHA, Leonardo Carneiro. Negócios Jurídicos Processuais no Direito Brasileiro. Disponível na internet. https://www.academia.edu/10270224. Acesso em 17 de abril de 2015, p. 14.

${ }^{26}$ Com relação à alteração da ordem probatória e sua viabilidade por iniciativa do juiz, o STJ já se manifestou favoravelmente, em decisão de 1994. "Ementa: Prova. Inversão na ordem prevista no art. 452 do CPC. Ausência de prejuízo. Além de não ser peremptória a ordem estabelecida no art. 452 do CPC, há parte de evidenciar o prejuízo que lhe adviria com a inversão ocorrida. Aplicação ao caso, ademais, da Súmula n. 283-STF. Recurso Especial não conhecido." STJ - REsp 35786 SP 1993/0016147-4. 4 ${ }^{a}$ Turma. Pub. em: 12.12.1994, DJ p. 34350, RSTJ, vol. 79, p. 238.

${ }^{27}$ BARBOSA MOREIRA, José Carlos. Convenção das partes sobre matéria processual. In: Temas de Direito Processual. 3 série. São Paulo: Saraiva, 1984, pp. 87-88.

${ }^{28}$ ARENHART, Sérgio Cruz; OSNA, Gustavo. Os "acordos processuais" no projeto do Novo CPC aproximações preliminares. Revista Eletrônica - Tribunal Regional do Trabalho do Paraná, v. 39, 2015. Disponível em: http://www.mflip.com.br/pub/escolajudicial/index.jsp?ipg=194778. Acesso em 20 abr 2015.
} 
Revista Eletrônica de Direito Processual - REDP.

Rio de Janeiro. Ano 12. Volume 19. Número 2. Maio a Agosto de 2018

Periódico Quadrimestral da Pós-Graduação Stricto Sensu em Direito Processual da UERJ

Patrono: José Carlos Barbosa Moreira (in mem.). ISSN 1982-7636. pp. 118-148 www.redp.uerj.br

doutrina $^{29}$, a seu turno, também tem feito grande contribuição no sentido de concretizar e consolidar o instituto.

Leonardo $\mathrm{Greco}^{30}$, por exemplo, sistematiza as convenções em três grupos: (i) aquelas que afetam apenas a direitos processuais das partes, sem interferir nas prerrogativas do órgão julgador, demonstrando-se, portanto, aptas a produzirem efeitos imediatos; (ii) aquelas que afetam os poderes do juiz, o que é autorizado por lei na hipótese de conjugação de intenção das partes, razão pela qual também produzem efeitos desde a avença; e (iii) aquelas nas quais a conjugação da vontade das partes deve ser somada à concordância do juiz, que fará uma análise da conveniência e oportunidade para que o acordo passe a surtir efeitos, haja vista a inexistência de autorização legal para a limitação dos poderes apenas pela conjugação da vontade dos litigantes.

Ainda segundo o autor ${ }^{31}$, as convenções processuais devem obedecer aos seguintes requisitos: (a) a possibilidade de autocomposição a respeito do próprio direito material posto em juízo ou a impossibilidade de que a convenção prejudique o direito material indisponível ou a sua tutela; (b) a celebração por partes plenamente capazes; (c) o respeito ao equilíbrio entre as partes e à paridade de armas, para que uma delas, em razão de atos de disposição seus ou de seu adversário, não se beneficie de sua particular posição de vantagem em relação à outra quanto ao direito de acesso aos meios de ação e de defesa; e (d) a preservação da observância dos princípios e garantias fundamentais do processo e da ordem pública processual.

Duas questões precisam ser esclarecidas: a) A primeira diz respeito à definiç̧ão do alcance da expressão ordem pública processual. Como bem sinaliza Diogo Rezende ${ }^{32}$, a expressão se refere a direitos públicos inafastáveis: são eles: (a.1) a igualdade e a capacidade das partes; (a.2) o contraditório e a ampla defesa; (a.3) o devido processo legal; (a.4) o princípio do juiz natural; (a.5) a independência e a imparcialidade do julgador; (a.6) a fundamentação das decisões judiciais; (a.7) a busca da verdade; (a.8) a celeridade; (a.9) a

\footnotetext{
${ }^{29}$ CAPONI, Remo. Autonomia privata e processo civile: gli accordi processuali. Accordi di Parte e Processo. Quaderni della Rivista Trimestrale di Diritto e Procedura Civile, ${ }^{\circ}{ }^{11}$. Milano: Giuffrè, 2008, pp. $105 / 111$.

${ }^{30}$ GRECO, Leonardo. O juiz pode ser sujeito de um negócio processual? Palestra proferida no Seminário "Negócios Processuais no Novo CPC" promovida pela Associação dos Advogados de São Paulo/SP - AASP, em 06 de março de 2015.

${ }^{31}$ GRECO, Leonardo. Instituições de Processo Civil - Introdução ao Direito Processual Civil. vol. 1, 5. ed, Rio de Janeiro: Forense, 2015, pp.61-62.

${ }^{32}$ ALMEIDA, Diogo Assumpção Rezende. Das Convenções Processuais no Processo Civil. Ob. Cit., p.149.
} 
Revista Eletrônica de Direito Processual - REDP.

Rio de Janeiro. Ano 12. Volume 19. Número 2. Maio a Agosto de 2018

Periódico Quadrimestral da Pós-Graduação Stricto Sensu em Direito Processual da UERJ

Patrono: José Carlos Barbosa Moreira (in mem.). ISSN 1982-7636. pp. 118-148 www.redp.uerj.br

coisa julgada material: e b) A segunda se refere à possibilidade da realização de convenções processuais mesmo quando está em jogo direito identificado como indisponível.

Nesse passo, importante reconhecer que com o advento do CPC/2015 (arts. 165 e $334, \S 4^{\circ}$ ) e da Lei de Mediação (art. $3^{\circ}, \S 2^{\circ}$ da Lei $\left.n^{\circ} 13.140 / 2015\right)$ não há mais dúvida quanto à possibilidade de composição em direitos indisponíveis.

Temos sustentado ${ }^{33}$ que, diante dos termos adotados pelo legislador, aliados à ideia da ressignificação da indisponibilidade a partir das premissas da contemporaneidade, a abrangência do direito indisponível que não admite autocomposição deve ser reduzida às hipóteses nas quais haja vedação expressa ao acordo, ou quando a disposição violentar um direito fundamental do cidadão.

O Código de 2015, com isso, traz a técnica de flexibilização do processo, o que acaba por acarretar um dinamismo diferente às condutas dos sujeitos processuais, permitindo, dessa forma, que as partes tenham uma maior contribuição sobre a gestão do processo.

A ideia encontra certa resistência, sobretudo em virtude da cultura da civil law brasileira, apegada à forma preestabelecida do ato e do procedimento, enquanto sinônimo de previsibilidade e segurança, bem como de ordem apta a garantir um tratamento isonômico a todos os envolvidos na relação jurídico-processual.

Essa mentalidade acaba se enraizando no ideário coletivo e, via de consequência, tornando difícil a abertura à atuação dispositiva dos particulares. De toda forma, maleabilizar-se o procedimento revela-se tendência natural e consequência inata à evolução dos parâmetros constitucionais e, por conseguinte, processuais.

Como tal, afastá-la equivaleria a manter o ordenamento processual brasileiro estagnado no tempo pré-Constituição, na contramão de alternativas viáveis para procedimentos preestabelecidos que, face ao caso concreto, mostrem-se não efetivos e, por isso mesmo, incompatíveis com o verdadeiro e pleno acesso à justiça e à tão visada tutela jurisdicional.

Trata-se, enfim, de apenas um dos muitos exemplos de inovações trazidas pela Lei

\footnotetext{
${ }^{33}$ Ver nossa exposição sobre Convenções Processuais, realizada no Auditório do Ministério Público de Minas Gerais, em agosto de 2015: http://humbertodalla.podomatic.com/entry/2015-08-19T07_10_28-07_00, acesso em 15 de novembro de 2015.
} 
Revista Eletrônica de Direito Processual - REDP.

Rio de Janeiro. Ano 12. Volume 19. Número 2. Maio a Agosto de 2018

Periódico Quadrimestral da Pós-Graduação Stricto Sensu em Direito Processual da UERJ

Patrono: José Carlos Barbosa Moreira (in mem.). ISSN 1982-7636. pp. 118-148

www.redp.uerj.br

$\mathrm{n}^{\mathrm{o}} 13.105 / 2015$. Por mais que algumas vozes, em doutrina ${ }^{34}$, apregoem que o Novo Código

não representa grande ruptura em relação a seu predecessor, são inúmeras as normas que

parecem apontar para o sentido oposto, sendo as convenções processuais apenas um desses

temas.

Nesse sentido, e seguindo tendência que já se verifica em outros ordenamentos jurídicos, o art. 190 permite às partes adaptar o procedimento às peculiaridades da causa, constituindo cláusula geral de negociação processual.

O grande desafio é encontrar o ponto de equilíbrio. De fato, é muito mais fácil visualizar as hipóteses de cabimento das convenções no plano teórico do que na prática. $\mathrm{O}$ NCPC, para mal ou para bem, só o tempo dirá, optou pela técnica da cláusula geral ao dispor sobre o novo instituto, ao mesmo tempo propiciando potenciais conquistas em termos de uma prestação jurisdicional mais ajustada às particularidades do litígio, e exigindo um estudo cauteloso e ponderado dos limites a serem observados.

Não há um rol de hipóteses ${ }^{35}$ nas quais a convenção é possível, mas sim uma autorização genérica subordinada a determinadas condições. O dispositivo prevê, para tanto, dois requisitos: um objetivo e outro subjetivo. Assim, o processo deve versar sobre direitos que admitam autocomposição ${ }^{36}$ e as partes devem ser capazes.

Quanto à autocomposição, nada mais é do que uma das formas de resolução de conflitos, tal como correntemente classificada pela doutrina tradicional ${ }^{37}$, que permite às

\footnotetext{
34 http://www.migalhas.com.br/Quentes/17,MI146096,71043-Antonio+Claudio+da+Costa+ Machado+ critica+proposta+de+reforma+do+CPC

${ }^{35}$ Não obstante a técnica legislativa, a doutrina tem manifestado grande preocupação com o tema. Nesse sentido, podem ser colhidos alguns enunciados do Fórum Permanente de Processualistas Civis, buscando identificar as hipóteses nas quais é possível ou não estabelecer convenções processuais: Enunciado $\mathrm{n}^{\circ} 19$ do FPPC: São admissíveis os seguintes negócios processuais, dentre outros: pacto de impenhorabilidade, acordo de ampliação de prazos das partes de qualquer natureza, acordo de rateio de despesas processuais, dispensa consensual de assistente técnico, acordo para retirar o efeito suspensivo de recurso, acordo para não promover execução provisória; pacto de mediação ou conciliação extrajudicial prévia obrigatória, inclusive com a correlata previsão de exclusão da audiência de conciliação ou de mediação prevista no art. 334; pacto de exclusão contratual da audiência de conciliação ou de mediação prevista no art. 334; pacto de disponibilização prévia de documentação (pacto de disclosure), inclusive com estipulação de sanção negocial, sem prejuízo de medidas coercitivas, mandamentais, sub-rogatórias ou indutivas; previsão de meios

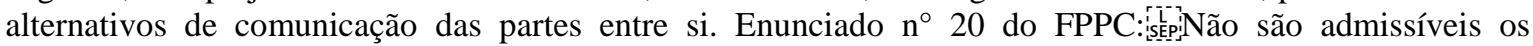
seguintes negócios bilaterais, dentre outros: acordo para modificação da competência absoluta, acordo para supressão da primeira instância. Enunciado $n^{\circ} 254$ do FPPC: É inválida a convenção para excluir a intervenção do Ministério Público como fiscal da ordem jurídica. Enunciado n ${ }^{\circ} 255$ do FPPC: É admissível a celebração de convenção processual coletiva.

${ }^{36}$ GODINHO, Robson. Convenções sobre o ônus da prova - estudo sobre a divisão de trabalho entre as partes e os juízes no processo civil brasileiro. Tese. PUC/SP, 2013.

${ }^{37}$ Sobre a autocomposição, destacamos, em outra obra, seu caráter residual no direito moderno, consistindo em “(...) solução parcial (por ato dos sujeitos em conflito) na qual as partes chegam a um acordo quanto à
} 
Revista Eletrônica de Direito Processual - REDP.

Rio de Janeiro. Ano 12. Volume 19. Número 2. Maio a Agosto de 2018

Periódico Quadrimestral da Pós-Graduação Stricto Sensu em Direito Processual da UERJ

Patrono: José Carlos Barbosa Moreira (in mem.). ISSN 1982-7636. pp. 118-148 www.redp.uerj.br

partes acordarem quanto à existência ou inexistência de um direito.

Há de se observar, assim, que direitos que admitam autocomposição são, em sua essência, disponíveis ou reflexos patrimoniais de direitos indisponíveis ${ }^{38}$.

Podem, ainda, ser de cunho material ou processual, ressalvando-se a impossibilidade de atingimento de norma processual de interesse público relevante. Somente as regras que interessem precipuamente às partes se enquadram no dispositivo, e, mesmo assim, desde que atentem para as indisponibilidades previstas na Lei civil.

Além desse requisito objetivo, o art. 190 faz menção a um de natureza subjetiva, ao exigir que as partes sejam plenamente capazes. A lógica da Lei é intuitiva: apenas aqueles que possuem aptidão plena para a prática dos atos da vida civil podem decidir sobre os rumos da tutela de seus direitos no processo.

Tal capacidade, para convenções elaboradas de forma endoprocessual, é aferida em seu tríplice aspecto: capacidade de ser parte, capacidade de estar em juízo e capacidade postulatória.

Já para aquelas realizadas na seara extrajudicial, em que pesem posições doutrinárias divergentes, Trícia Navarro sustenta a necessidade tão só da capacidade de ser parte, até o momento de ingresso no processo, uma vez que sua natureza seria de ato material $^{39}$.

Preenchidos ambos os requisitos, podem ser realizados acordos processuais versando sobre: a) ônus; b) poderes; c) faculdades; e d) deveres.

O acordo pode ser prévio (realizado antes do processo, por exemplo, em uma cláusula contratual) ou incidental (quando já iniciada a relação processual).

$\mathrm{O}$ art. $357, \S 2^{\circ}$, que trata da decisão de saneamento, prevê ainda que as partes podem apresentar ao juiz, para homologação, delimitação consensual das questões de fato e de direito.

$\mathrm{O}$ art. 373, § 30, dispõe que a distribuição diversa do ônus da prova também pode ocorrer por convenção das partes, salvo quando recair sobre direito indisponível da parte

existência ou inexistência de um direito, seja pela renúncia, pela transação (concessões recíprocas) ou mediante o reconhecimento da pretensão alheia, pondo fim ao conflito de interesses existente." PINHO, Humberto Dalla Bernardina de. Teoria geral do processo civil contemporâneo. 3. ed. Rio de Janeiro: Lumen Juris, 2010, p. 27.

${ }^{38}$ MARTEL, Letícia de Campos Velho. Indisponibilidade dos Direitos Fundamentais: conceito lacônico, consequências duvidosas. Espaço Jurídico, v. 11, p. 334-373, julho/dezembro de 2010.

${ }^{39}$ CABRAL, Trícia Navarro Xavier. Convenções em matéria processual. Revista de Processo, vol. 241/2015, p. $489-516, \mathrm{mar} / 2015$. 
Revista Eletrônica de Direito Processual - REDP.

Rio de Janeiro. Ano 12. Volume 19. Número 2. Maio a Agosto de 2018

Periódico Quadrimestral da Pós-Graduação Stricto Sensu em Direito Processual da UERJ

Patrono: José Carlos Barbosa Moreira (in mem.). ISSN 1982-7636. pp. 118-148

www.redp.uerj.br

ou tornar excessivamente difícil a uma parte o exercício do direito.

E, ainda, o art. 471 dispõe que as partes podem, de comum acordo, escolher o perito, indicando-o mediante requerimento, desde que sejam plenamente capazes e a causa possa ser resolvida por autocomposição.

São todas expressões concretas do princípio da cooperação, genericamente disposto no art. 6- do CPC/2015.

Retornando ao art. 190, seu parágrafo único determina que o magistrado, ex officio ou mediante provocação da parte interessada, deverá controlar a validade das convenções, sobretudo a fim de preservar os princípios constitucionais ${ }^{40}$, observando os limites impostos pela ordem pública processual.

Ao examinar a convenção, o juiz pode homologá-la, ou, excepcionalmente, recusála, somente nos seguintes casos: a) configuração de nulidade; b) inserção abusiva em contrato de adesão; c) quando uma das partes se encontre em manifesta situação de vulnerabilidade.

Para Fernanda Tartuce ${ }^{41}$, vulnerabilidade significa suscetibilidade. É possível falarse, ainda, em vulnerabilidade processual ${ }^{42}$.

Necessário, aqui, estabelecer em qual sentido o termo dever ser interpretado. Temos para nós que a vulnerabilidade, aqui, é somente a processual, devendo ser aferida pelo magistrado diante das peculiaridades do caso concreto.

Em matéria de direitos transindividuais, em princípio, as convenções processuais podem ser utilizadas tanto na fase pré-judicial (no inquérito civil, por exemplo) como durante a ação civil pública.

Nesse sentido, os arts. 15 a 17 da Resolução n 118/2014 do Conselho Nacional do Ministério Público admitem, expressamente, o uso de tais instrumentos como ferramentas de proteção aos direitos coletivos pelo Ministério Público.

$\mathrm{O}$ art. 16 dispõe que "poderá o membro do Ministério Público, em qualquer fase da

\footnotetext{
${ }^{40}$ BEDAQUE, José Roberto dos Santos. Tutela cautelar e tutela antecipada: tutelas sumárias e de urgência (tentativa de sistematização). 4. ed. São Paulo: Malheiros, 2006, p. 168.

41 "Vulnerabilidade indica suscetibilidade em sentido amplo, sendo a hipossuficiência uma de suas espécies (sob o viés econômico) ". TARTUCE, Fernanda. Vulnerabilidade Processual no novo CPC, artigo disponível no seguinte endereço: https://www.academia.edu/25885818/Vulnerabilidade_processual_no_Novo_CPC, acesso em 05 de junho de 2016.

42 "Vulnerabilidade processual é a suscetibilidade do litigante que o impede de praticar atos processuais em razão de uma limitação pessoal involuntária; a impossibilidade de atuar pode decorrer de fatores de saúde e/ou de ordem econômica, informacional, técnica ou organizacional de caráter permanente ou provisório". TARTUCE, Fernanda. Igualdade e Vulnerabilidade no Processo Civil. São Paulo: Método, 2012, p. 184.
} 
Revista Eletrônica de Direito Processual - REDP.

Rio de Janeiro. Ano 12. Volume 19. Número 2. Maio a Agosto de 2018

Periódico Quadrimestral da Pós-Graduação Stricto Sensu em Direito Processual da UERJ

Patrono: José Carlos Barbosa Moreira (in mem.). ISSN 1982-7636. pp. 118-148 www.redp.uerj.br

investigação ou durante o processo, celebrar acordos visando constituir, modificar ou extinguir situações jurídicas processuais" e o art. 17 permite, que as convenções sejam "documentadas como cláusulas de termo de ajustamento de conduta".

No que se refere ao eventual cabimento das convenções em relações consumeristas, contudo, temos algumas dificuldades.

Em primeiro lugar, o art. $1^{\circ}$ do $\mathrm{CDC}$ estabelece que as normas ali elencadas são de ordem pública. Em seguida, o art. $4^{\circ}$ reconhece expressamente a vulnerabilidade do consumidor no mercado de consumo. Ademais, o art. $6^{\circ}$, que trata dos direitos básicos do consumidor assegura: a) a proteção contra práticas e cláusulas abusivas ou impostas no fornecimento de produtos e serviços (inciso IV); b) a vedação à modificação das cláusulas contratuais que estabeleçam prestações desproporcionais ou excessivamente onerosas (inciso V); e c) a facilitação defesa de seus direitos, inclusive com a inversão do ônus da prova, a seu favor (inciso VIII).

Finalmente o art. 51, VI estabelece serem nulas de pleno direito as cláusulas contratuais relativas ao fornecimento de produtos e serviços que estabeleçam inversão do ônus da prova em prejuízo do consumidor;

Não se está dizendo, com isso, que haverá uma proibição absoluta. Contudo, forçoso reconhecer que, diante de todas as restrições apontadas acima, será bastante improvável que o Judiciário admita convenções processuais prévias ou incidentais em processos envolvendo relações de consumo.

\section{Um olhar comparativo sobre o instituto do settlemente nas class actions do} direito norte-americano

Dentro do novo contexto processual civil pátrio, a partir do lineamento do CPC de 2015 e da Lei de Mediação, forçando a necessidade de reanálise sobre o alcance da negociação do compromisso de ajuste de conduta, tradicionalmente limitada a aspectos anexos da obrigação, o estudo da figura da class action settlement, prevista na legislação norte-americana, mostra-se interessante, em razão da extensa margem de negociação que possui $^{43}$.

\footnotetext{
${ }^{43}$ Em texto escrito em 1971, Richard Dole previa um future promissor para os acordos em questões coletivas: "The challenge of providing appropriate procedures for the resolution of representative actions is substantial and continuing. Further experience with enlightened settlement techniques should do much to
} 
Revista Eletrônica de Direito Processual - REDP.

Rio de Janeiro. Ano 12. Volume 19. Número 2. Maio a Agosto de 2018

Periódico Quadrimestral da Pós-Graduação Stricto Sensu em Direito Processual da UERJ

Patrono: José Carlos Barbosa Moreira (in mem.). ISSN 1982-7636. pp. 118-148 www.redp.uerj.br

De início, deve-se notar que o método prevalente nas resoluções de controvérsias é um dos pontos de distinção mais significativo entre as culturas jurídicas romano-germânica e anglo-saxã. No civil law, ao menos na tradição original, tem-se uma concepção precipuamente litigiosa do processo, enquanto, no cenário de common law, sobretudo nos EUA, as demandas raramente são submetidas ao trial, sendo resolvidas em acordos entre as partes ${ }^{44}$.

Importante observar que Brian Fitzpatrick ${ }^{45}$ nos dá uma ideia bastante clara do enorme crescimento dos acordos em ações coletivas aprovados por Cortes norteamericanas, sobretudo se comparado às conclusões apresentadas anos antes pelo estudo feito por Theodore Eisenbert e Geoffrey Miller ${ }^{46}$.

Com efeito, o contexto estadunidense é condizente com a valorização que o país confere à ideologia liberal, em especial ao princípio da autonomia da vontade. Nesse ideário, o juiz não exerce qualquer atividade nos acordos individuais, sendo inexistente naquela ordem jurídica o conceito de "direitos indisponíveis", tal como conhecemos.

A Rule 41(a) (1) prevê que a partir do momento em que as partes estiverem de pleno acordo, o processo prescindirá de homologação judicial para ser extinto ${ }^{47}$. Excepcionalmente, o legislador exige a aprovação judicial para o acordo. Assim, no contexto das ações coletivas ${ }^{48}$, para que um acordo coletivo seja eficaz e vincule os

meet that challenge". DOLE Jr., Richard F. The Settlement of Class Actions for Damages. 71 Colum. L. Rev. 971.

${ }^{44}$ PINHO, Humberto Dalla Bernardina de. VIDAL, Ludmilla Camacho Duarte. Primeiras reflexões sobre os impactos do novo CPC e da lei de mediação no compromisso de ajustamento de conduta, in Revista de Processo, vol. 256, ano 41, jun/2016, Revista dos Tribunais: São Paulo, p. 382.

45 'I found 688 settlements approved by federal district courts during 2006 and 2007 using the methodology described above. This is almost the exact same number the Eisenberg-Miller study found over a sixteen-year period in both federal and state court. Indeed, the number of annual settlements identified in this study is several times the number of annual settlements that have been identified in any prior empirical study of class action settlements. Of the 688 settlements I found, 304 of these settlements were approved in 2006 and 384 were approved in 2007". Fitzpatrick, Brian T. An Empirical Study of Class Action Settlements and Their Fee Awards. 7 Journal of Empirical Legal Studies (forthcoming 2010). Acesso em: http://ssrn.com/abstract=1442108, em 15 de novembro de 2017, p. 9.

${ }^{46}$ EISENBERT, Theodore. MILLER, Geoffrey P. Attorney Fees in Class Action Settlements: An Empirical Study. Journal of Empirical Legal Studies Volume 1, Issue 1, 27-78, March 2004. Electronic copy available at: htttp://scholarship.law.cornell.edu/facpub/356/, accesso em 3 de dezembro de 2017.

47 "Rule 41. Dismissal of Actions: (a) Voluntary Dismissal. (1) By the Plaintiff. (A) Without a Court Order. Subject to Rules 23(e), 23.1(c), 23.2, and 66 and any applicable federal statute, the plaintiff may dismiss an action without a court order by filing: (i) a notice of dismissal before the opposing party serves either an answer or a motion for summary judgment; or (ii) a stipulation of dismissal signed by all parties who have appeared".

${ }^{48}$ FISS, O.M. Against Settlement, 93 Yale Law Journal 1073-90, May 1984, p. 1443. 
Revista Eletrônica de Direito Processual - REDP.

Rio de Janeiro. Ano 12. Volume 19. Número 2. Maio a Agosto de 2018

Periódico Quadrimestral da Pós-Graduação Stricto Sensu em Direito Processual da UERJ

Patrono: José Carlos Barbosa Moreira (in mem.). ISSN 1982-7636. pp. 118-148

www.redp.uerj.br

indivíduos que não tiveram o seu "day in court", o Poder Judiciário deve reputá-lo

adequado à defesa de todos os interesses dos membros da classe.

E aqui é preciso enfatizar a grande controvérsia na doutrina norte-americana acerca

da real efetividade desses acordos em matéria coletiva. Desde autores que sustentam o banimento do instituto ${ }^{49}$, ou mesmo que deveria receber regras mais rígidas.

Contudo, apesar das sucessivas reformas implementadas, a fim de aprimorar a redação tanto da Regra 23 das FRCP, como do US Code, os tribunais ainda tem que enfrentar questões tormentosas, envolvendo, por exemplo: i) conflitos intra-classe ${ }^{50}$, ii) desproporcionalidade do valor dos honorários advocatícios, se comparados ao valor a ser recebido por cada membro da classe ${ }^{51}$, iii) falta de parâmetros legais que possam orientar a extensão do acordo $^{52}$ e o grau de discricionariedade do juízo para aprovar ou não o

49 "It is time to abandon the settlement class action. Notwithstanding the device's attractiveness to defendants, to plaintiffs' counsel, and to judges as a means of achieving comprehensive resolutions, it does not withstand scrutiny as a legitimate exercise of judicial authority. There is no sound basis on which a settlement class action, in the absence of litigation class certification, should bind class members. We need to be clear on what a settlement class action is, or more precisely, what it is not. It is not a contract, at least not in the sense of an agreement to which the class members are parties. It is not an adjudication on the merits. Rather, it is an act of judicial power premised on a negotiated resolution. But the underlying negotiation has the odd characteristic that the negotiator for the claimants is a prospective agent who has neither been authorized to act on behalf of the claimants nor been granted the power to take their claims to trial. This feature creates an asymmetrical dynamic that negates any argument that the act of judicial power is justified by a presumption of fair valuation of claims. The problem is not one of collusion or bad faith, but rather a structural problem built into the very definition of a settlement class action”. ERICHSON, Howard M. The Problem of Settlement Class Action. 82 Geo. Wash. L. Rev. 951. Acesso por meio do sítio Westlaw, em 9 de janeiro de 2018.

${ }^{50}$ And there is also the stormy question of conflicts within the class and the consequent need to make the agreement fair and adequate for all. "But late twentieth century sensibilities regarding the nature of class conflicts that might threaten adequate representation, regarding the role of conflicts management in assuring adequate representation, and regarding sub-classing as the vehicle for achieving it, all now seem quaint and out of touch with current institutional arrangements. It's high time to recognize the collapse of the class conflicts management regime announced in Amchem and Ortiz and to acknowledge the contours of the new regime emerging in its stead". RATNER, Morris A. Class Conflicts, 92 Wash. L. Rev. 785. Acesso por meio do sítio Westlaw, em 11 de janeiro de 2018.

${ }^{51}$ The proposed settlement presented in In re Electronic failed in two regards. The court caught the first with its Reed-factor analysis, finding the actual terms of the settlement to be "not in the best interests of the proposed class members." And while the court recognized the second--the discrepancy between the class's recovery and the attorneys' fees - a more thorough opinion would have employed a Johnson-factor analysis to better illuminate the court's misgivings and avoid the possibility of reversal. Though it can be argued that an otherwise acceptable settlement should be approved despite misgivings about fees, a settlement unacceptable in both terms and the amount of attorneys' fees should never be accepted. In the end, "Chevrolet-type results do not warrant Cadillac-size legal fees." ALMON, Matthew. Cadillac-Size Legal Fees" and "Chevrolet-Type Results": Settlement Scrutiny in Re Electronic Data Systems Corp. "Erisa" Litigation, 80 Tul. L. Rev. 2007. Acesso por meio do sítio Westlaw em 12 de janeiro de 2018.

52 "Specifically, we propose that for questions going to the adequacy of a settlement, where no warning signals of fraud or collusion are found, the court should act relatively deferentially by employing a lenient standard of scrutiny and approving a settlement if it has a rational basis. An intermediate level of scrutiny should apply when the settlement presents facial issues that implicate the fairness of the settlement. Such facial issues include the allocation of settlement proceeds among subgroups in a class, the presence of 
Revista Eletrônica de Direito Processual - REDP.

Rio de Janeiro. Ano 12. Volume 19. Número 2. Maio a Agosto de 2018

Periódico Quadrimestral da Pós-Graduação Stricto Sensu em Direito Processual da UERJ

Patrono: José Carlos Barbosa Moreira (in mem.). ISSN 1982-7636. pp. 118-148

www.redp.uerj.br

acordo $^{53}$, e iv) a ausência de efetividade do acordo para os membros efetivamente lesados

pela conduta praticada pelo réu ${ }^{54}$.

Por isso, o ordenamento, por um lado, traz expressa previsão de possibilidade de ajustes entre as partes nas três hipóteses ${ }^{55}$ de ações coletivas contempladas pela Regra 23 , ao mesmo tempo que impõe requisitos especiais para o seu aperfeiçoamento ${ }^{56}$. Não custa

coupon-type relief, "shotgun" settlements occurring very early in the litigation, and settlements in overlapping class actions. In settlements with one or more of these characteristics, if the initial inquiry raises concerns, the court should demand a well-reasoned explanation for the choices made. Finally, where the components of a settlement present a direct conflict between the interests of class counsel and those of the class issues, such as issues related to attorneys' fees, courts should employ exacting scrutiny and require convincing evidence that the proposal is reasonable”. Jonathan R. Macey. Geoffrey P. Miller. Judicial Review of Class Action Settlements, 1 J. Legal Analysis 167. Acesso por meio do sítio Westlaw em 15 de janeiro de 2018.

53 "The confusion and inconsistency in standards for review of class action settlements is due to a failure to recognize that different levels of scrutiny are suited to different questions. Courts should apply lenient scrutiny on questions going to the settlement's adequacy, requiring only plausible justifications for decisions made in the absence of indicia of fraud, collusion, or conflict of interest. Courts should apply intermediate scrutiny to concerns about fairness--allocation issues, coupon relief, shotgun settlements, and potential "reverse auction" settlements in overlapping cases-- and should insist on well-reasoned explanations for why these concerns are unfounded. Exacting scrutiny is required for counsel fees. Overall, Rule 23(e)' s requirement that a settlement be "reasonable" should be administered flexibly depending on the issue involved". MACEY, Jonathan R. MILLER, Geoffrey P. Judicial Review of Class Action Settlements, 1 J. Legal Analysis 167. Acesso por meio do sítio Westlaw em 16 de janeiro de 2018.

54 "The class action settlement is a business deal, a contract, between skilled negotiators (...). Yet it too is a contract that cannot stand on its own feet. The class action settlement lacks stability not because the masses have so much at stake that they are well informed and impassioned, but rather because the masses have so little at stake that they are ignorant and indifferent. The problem is not that their agents have sold them out, but that they do not even know they have agents. In the face of this apathy, the task once again falls to a court to legitimate the deal--and what better way to do so than to hold a hearing and name it "fairness." (...) If the fairness hearing is to be anything more than dissimulation, the legal system must arm judges with tools that will enable them to do the job for real". RUBENSTEIN, William B. Emerging Issues in Class Action Law. 53 UCLA L. Rev. 1435. Acesso por meio do sítio Westlaw em 18 de janeiro de 2018.

${ }_{55}$ Class actions which are certified on basis that prosecution of separate actions would create risk of inconsistent or varying adjudications, or impairment of ability of nonparties to protect their interests, do not provide for absent class members to receive notice and to exclude themselves from class membership as a matter of right, and for this reason are often referred to as "mandatory class actions." Fed. Rules Civ. Proc. Rule 23(b)(1), 28 U.S.C. A. Ortiz v. Fibreboard Corp., 527 U.S. 815 (1999).

${ }^{56}$ Trata-se da regra prevista na alínea (e) da Regra 23 das Federal Rules of Civil Procedure: (e) Settlement, Voluntary Dismissal, or Compromise. The claims, issues, or defenses of a certified class may be settled, voluntarily dismissed, or compromised only with the court's approval. The following procedures apply to a proposed settlement, voluntary dismissal, or compromise: (1) The court must direct notice in a reasonable manner to all class members who would be bound by the proposal. (2) If the proposal would bind class members, the court may approve it only after a hearing and on finding that it is fair, reasonable, and adequate. (3) The parties seeking approval must file a statement identifying any agreement made in connection with the proposal. (4) If the class action was previously certified under Rule 23(b)(3), the court may refuse to approve a settlement unless it affords a new opportunity to request exclusion to individual class members who had an earlier opportunity to request exclusion but did not do so. (5) Any class member may object to the proposal if it requires court approval under this subdivision (e); the objection may be withdrawn only with the court's approval. 
Revista Eletrônica de Direito Processual - REDP.

Rio de Janeiro. Ano 12. Volume 19. Número 2. Maio a Agosto de 2018

Periódico Quadrimestral da Pós-Graduação Stricto Sensu em Direito Processual da UERJ

Patrono: José Carlos Barbosa Moreira (in mem.). ISSN 1982-7636. pp. 118-148

www.redp.uerj.br

lembrar que no caso dos chamados "coupon settlements" existe, ainda, uma regra especial no US Code ${ }^{57}$.

De início, há uma previsão de natureza genérica, qual seja, a prévia aprovação de seus termos pelo tribunal ${ }^{58}$.

Além dela, a Regra 23 (e) estabelece outras em seus itens (1) a (5), sendo que a prevista no item (4) refere-se exclusivamente às ações de classe certificadas sob a Regra (b) 3 e dispõe que o tribunal poderá recusar a aprovação de um acordo, a menos que se assegure aos membros do grupo uma nova oportunidade de exercer o seu direito de autoexclusão da ação ${ }^{59}$, o que não se verifica no direito brasileiro, e se constitui objeto de forte crítica doutrinária ${ }^{60}$.

Há, destarte, uma maior cautela com a necessidade de notificação dos membros da classe em uma ação pautada na Regra 23 (b) 3, coerente com o aspecto individual dos interesses em disputa ${ }^{61}$.

Assim, o juiz tem a função de garantir os direitos dos membros ausentes e os direitos do grupo, que poderiam ser violados caso essa previsão não existisse ${ }^{62}$. Dentro desse quadro, a pretensão, na origem, será individual, até que o representante da classe requeira a chamada motion for certification, requerimento por meio do qual postula o

\footnotetext{
${ }^{57} 28$ USC. § 1712. Coupon settlements. (...) (e) Judicial scrutiny of coupon settlements. In a proposed settlement under which class members would be awarded coupons, the court may approve the proposed settlement only after a hearing to determine whether, and making a written finding that, the settlement is fair, reasonable, and adequate for class members. The court, in its discretion, may also require that a proposed settlement agreement provide for the distribution of a portion of the value of unclaimed coupons to 1 or more charitable or governmental organizations, as agreed to by the parties. The distribution and redemption of any proceeds under this subsection shall not be used to calculate attorneys' fees under this section. https://www.law.cornell.edu/uscode/text/28/1712, access em 17 de janeiro de 2018.

${ }^{58}$ In deciding whether to grant preliminary approval of proposed class action settlement, court determines whether proposed settlement discloses grounds to doubt its fairness or other obvious deficiencies such as unduly preferential treatment of class representatives or segments of class, or excessive compensation of attorneys, and whether it appears to fall within range of possible approval. Fed. Rules Civ. Proc. Rule 23(e), 28 U.S.C. A. In re National Football League Players' Concussion Injury Litigation, 301 F.R.D. 191 (2014).

59 "Reasonable settlement notice may require individual notice in the manner required by Rule 23(c)(2)(B) for certification notice to a Rule 23(b)(3) class. Individual notice is appropriate, for example, if class members are required to take action - such as filing claims - to participate in the judgment, or if the court orders a settlement opt-out opportunity under Rule 23(e)(3)." Committee Notes on Rules. 2003 Amendment, Disponível em: < http://www.law.cornell.edu/rules/frcp/rule_23 >. Acesso em 18 de junho de 2013.

${ }^{60}$ GIDI, Antonio. A Class Action como instrumento de tutela coletiva de direitos. São Paulo: Revista dos Tribunais, 2007, p. 326.

${ }^{61}$ In order to justify a departure from usual rule that litigation is conducted by and on behalf of individual named parties only, class representative must be part of class and possess same interest and suffer same injury as class members. Fed. Rules Civ. Proc. Rule 23, 28 U.S.C.A. Wal-Mart Stores, Inc. v. Dukes, 564 U.S. 338 (2011).

${ }_{62}$ PINHO, Humberto Dalla Bernardina de. The Undertaking of Adjustment Of Conduct In Brazilian Collective Procedural Law. Connecticut Journal of International Law. Vol, 27: 346, Spring 2012, p. 185.
} 
Revista Eletrônica de Direito Processual - REDP.

Rio de Janeiro. Ano 12. Volume 19. Número 2. Maio a Agosto de 2018

Periódico Quadrimestral da Pós-Graduação Stricto Sensu em Direito Processual da UERJ

Patrono: José Carlos Barbosa Moreira (in mem.). ISSN 1982-7636. pp. 118-148

www.redp.uerj.br

reconhecimento, no caso, das condições prescritas ao processamento de uma lide na forma coletiva $^{63}$.

Existe, ainda, a possibilidade de a negociação ter se dado extrajudicialmente ${ }^{64}$. Na espécie, ambas as partes ingressam com um pedido de certificação "as a class action for settlement purposes only", de modo que o juiz se pronuncie sobre a representatividade adequada da parte que substituiu a classe ${ }^{65}$.

Nesse caso utiliza-se a expressão settlement class action ${ }^{66}$, diferenciando-se da class action settlement por já existir um acordo prévio à propositura da demanda, que se volta a conferir eficácia erga omnes à composição já atingida, não tratando, então, de acordo obtido após a certificação da demanda coletiva.

A submissão aos acordos, às vezes mesmo desvantajosos ou injustos, é interessante ao réu para evitar os danos marginais causados por uma demanda de grandes repercussões.

A função da certification - ou certificação -, portanto, é a de ser um divisor de águas entre a ação individual e aquela de vultuosas dimensões com todas as suas particularidades $^{67}$, cuja verificação fortalece o poder de barganha da classe em relação ao réu.

Passada a certificação, além do fortalecimento da posição jurídica do demandante, o demandado vê no acordo uma alternativa para a vinculação definitiva em relação a todos os membros da classe.

\footnotetext{
${ }^{63}$ FISS, O.M. The Class Action Rule, 78 Notre Dame Law Review, 1419 (2003).

${ }^{64}$ PINHO, Humberto Dalla Bernardina de. VIDAL, Ludmilla Camacho Duarte. Primeiras reflexões sobre os impactos do novo CPC e da lei de mediação no compromisso de ajustamento de conduta, in Revista de Processo, vol. 256, ano 41, jun/2016, Revista dos Tribunais: São Paulo, p. 389.

${ }^{65}$ Asbestos products manufacturers who were members of Center for Claims Resolution (CCR), and whose stipulation of proposed global settlement of claims by persons exposed to asbestos had been court-approved, moved to enjoin actions against them by individuals who failed to timely opt out of class. The United States District Court for the Eastern District of Pennsylvania, Lowell A. Reed, Jr., J., 878 F. Supp. 716, granted injunction under All-Writs Act and Anti-Injunction Act. Parties objecting to class certification appealed, and the Court of Appeals for the Third Circuit, 83 F.3d 610, vacated and remanded with directions to decertify class. Certiorari was granted, and the Supreme Court, Justice Ginsburg, held that: (1) district court faced with request for settlement-only class certification need not inquire whether case would present intractable problems of trial management, but other requirements for certification must still be satisfied, abrogating In re Asbestos Litigation, 90 F.3d 963, White v. National Football League, 41 F.3d 402, In re A.H. Robins Co., 880 F.2d 709, and Malchman v. Davis, 761 F.2d 893, and (2) requirements for class certification of commonality of issues of fact and law and adequacy of representation were not met. Amchem Products, Inc. v. Windsor, 521 U.S. 591 (1997). Acesso por meio do sítio westlaw, em 20 de janeiro de 2018.

${ }^{66}$ ROQUE, Andre Vasconcelos. Class actions - ações coletivas nos Estados Unidos: o que podemos aprender com eles? Salvador: Juspodivm, 2013, p. 379.

${ }^{67}$ FISS, O.M. The political theory of the class action. Washington and Lee Law Review vol. 53 (1996), pp. $21 / 31$.
} 
Revista Eletrônica de Direito Processual - REDP.

Rio de Janeiro. Ano 12. Volume 19. Número 2. Maio a Agosto de 2018

Periódico Quadrimestral da Pós-Graduação Stricto Sensu em Direito Processual da UERJ

Patrono: José Carlos Barbosa Moreira (in mem.). ISSN 1982-7636. pp. 118-148

www.redp.uerj.br

Outro aspecto que contribui para o número elevado de acordos é o interesse do advogado do grupo em ver seu investimento desde já recuperado, evitando os riscos de prejuízos decorrentes de uma futura e eventual improcedência. No contexto norteamericano, o patrono é quem geralmente arca com os custos necessários ao processamento da demanda coletiva, no intento de auferir os lucros de um investimento que, em tese, compensem os riscos assumidos.

No momento de validar o acordo coletivo apresentado, a partir da Rule 23, subdivisão (e), o juiz deve aferir se a avença é justa, adequada e razoável ${ }^{68}$. Mesmo sendo conceitos jurídicos indeterminados, o Manual for Complex Litigation, semelhante a uma compilação de orientações jurisprudenciais às Cortes Federais, traz balizas metodológicas para a correta aplicação desses critérios após a reforma de $2004^{69}$.

A análise da justiça do ajuste baseia-se no tratamento adequado dado pela negociação em relação aos membros ausentes da classe. Verifica-se, por exemplo, se há uma posição injustificada de vantagens entre os integrantes do grupo que estavam ou não presentes na classe no momento da negociação ${ }^{70}$.

A adequação e a razoabilidade, por sua vez, são aferidas por uma ponderação entre as vantagens apresentadas pelo acordo e a probabilidade de êxito em uma demanda coletiva, cujo exame deve ser realizado casuisticamente ${ }^{71}$.

Trazendo, então, essas ideias à nossa realidade, o advento do art. 174, inciso III, do Código de 2015 e dos arts. $3^{\circ} \S 2^{\circ}$ e 32 , inciso III, da Lei $\mathrm{n}^{\circ} 13.140 / 2015$, conforme vimos acima, trouxe à tona a possibilidade de se negociar sobre o próprio fundo do direito

\footnotetext{
${ }^{68}$ In evaluating the fairness of a proposed class action settlement, court considers: (1) the strength of plaintiffs' case compared to the amount of defendants' settlement offer; (2) an assessment of the likely complexity, length, and expense of the litigation; (3) an evaluation of the amount of opposition to settlement among affected parties; (4) the opinion of competent counsel; and (5) the stage of the proceedings and the amount of discovery completed at the time of settlement. Fed. R. Civ. P. 23(e)(3). In re Capital One Telephone Consumer Protection Act Litigation, 80 F.Supp.3d 781 (2015).

${ }^{69}$ Disponível em: https://public.resource.org/scribd/8763868.pdf, p. 351. Acesso em 10 out 2015.

${ }^{70}$ On the other hand, some appellate courts have rejected settlements when the record reflects a lack of careful consideration by the district court. For instance, in Reynolds v. Beneficial National Bank, 288 F.3d 277 (7th Cir. 2002), the Seventh Circuit, in an opinion by Judge Posner, overturned a class settlement on the ground that the trial court should have made a greater effort (he made none) to quantify the net expected value of continued litigation to the class, since a settlement for less than that value would not be adequate. Determining that value would require estimating the range of possible outcomes and ascribing a probability to each point on the range [discounted to present value]. KLONOFF, Robert. Class Actions and Other MultiParty Litigation in a Nutshell. West Academic, 2017. Kindle's edition.

${ }^{71}$ PINHO, Humberto Dalla Bernardina de. VIDAL, Ludmilla Camacho Duarte. Primeiras reflexões sobre os impactos do novo CPC e da lei de mediação no compromisso de ajustamento de conduta, in Revista de Processo, vol. 256, ano 41, jun/2016, Revista dos Tribunais: São Paulo, p. 393.
} 
coletivo. Houve, então, uma inspiração no Direito norte-americano em aspecto até então negligenciado pelo Direito brasileiro ${ }^{72}$ ?

O ponto mais controvertido parece ser o fato de que, apesar de o art. 32, inciso III, ter colhido inspirações no settlement, não colocou a homologação judicial como pressuposto para a produção dos efeitos da estipulação coletiva, já que, de um lado, o TAC possui, legalmente, eficácia de título executivo extrajudicial, e, de outro, as instituições privadas podem propor mediação ao causador do dano coletivo e o termo de acordo é desde logo eficaz.

O controle do Poder Judiciário, nos EUA, aparece como ponto fundamental para assegurar que o acordo seja vantajoso para aqueles que não participaram da sua formação diretamente, já que a coisa julgada, nos termos ajustados, será produzida erga omnes.

Sendo uma decisão em princípio imutável ${ }^{73}$, antes da chancela judicial do acordo, todos os interessados (membros ausentes) deverão ser intimados por vias apropriadas ao caso, conforme a previsão na Rule 23 (e). Além disso, a homologação realizada sempre em audiência pública (fairness hearing), precedida de discussões, apresentação de objeções e sustentações sobre a justiça, adequação e efetividade do acordo.

O sistema sofisticado de controle casuístico da adequação do representante do grupo escolhido em juízo (ideological plaintiff) garante sua ampla legitimidade para negociar sobre os direitos de uma classe ${ }^{74}$. Assim, o juiz deve atestar, no caso concreto, as condições do autor da ação coletiva para representar os interesses do grupo na qualidade de named plaintiff.

No Brasil, para a propositura da demanda coletiva ou para o oferecimento do compromisso de ajustamento de conduta - judicial e extrajudicial -, tem-se que a legitimação extraordinária é concorrente e disjuntiva, em respeito à inafastabilidade do controle jurisdicional, constitucionalmente assegurada (art. $5^{\circ}$, inciso XXXV, CF).

É concorrente pela pluralidade de legitimados para a autoria da ação ou para o oferecimento do acordo, além de ser disjuntiva pela desnecessidade de um colegitimado ter o consentimento dos demais para agir. Ainda que tal situação seja, potencialmente, um fator de comprometimento do grau de definitividade do compromisso, essa configuração é

\footnotetext{
${ }^{72}$ PINHO, Humberto Dalla Bernardina de. O Marco Legal da Mediação no Brasil: Comentários à Lei n 13.140/15.1 ed. São Paulo: Atlas, 2015, p. 17.

${ }^{73}$ GIDI, Antonio. Class action in Brazil - a model for civil law countries. The American Journal of Comparative Law, v. 51, n. 2, 2003, p. 26.

${ }^{74}$ FISS, O.M. Against Settlement, 93 Yale Law Journal 1073-90, May 1984, p.1.444.
} 
Revista Eletrônica de Direito Processual - REDP.

Rio de Janeiro. Ano 12. Volume 19. Número 2. Maio a Agosto de 2018

Periódico Quadrimestral da Pós-Graduação Stricto Sensu em Direito Processual da UERJ

Patrono: José Carlos Barbosa Moreira (in mem.). ISSN 1982-7636. pp. 118-148

www.redp.uerj.br

importante para abarcar todas as possibilidades de defesa dos direitos da coletividade, considerando que as situações jurídicas sobre os direitos metaindividuais podem estabelecer entre si uma relação marcantemente conflituosa ${ }^{75}$.

Algumas medidas podem ser adotadas também para se fortalecer a estabilidade da pactuação. Deve-se, por exemplo, buscar a notificação prévia do maior número de interessados possível para que possam comparecer em audiência pública antes do encerramento do procedimento do TAC. É possível, ainda, buscar-se a participação dos demais colegitimados e de órgãos e entidades para atuarem como amicus curiae.

A oitiva dos demais legitimados mostra-se importante para que não haja o ajuizamento posterior de eventuais demandas sobre a mesma matéria, ante a insatisfação como compromisso firmado, gerando as intermináveis discussões acerca de litispendência e coisa julgada que se vê atualmente.

Eventuais atrasos para a conclusão do termo são compensados pela prevenção de problemas posteriores, ainda mais se considerando que se trata de uma instância de consenso, em que se deve conceder a oportunidade para todos se manifestarem e contribuírem com o debate.

As considerações registradas levam-nos à seguinte indagação: na medida em que agora se admite, expressamente, a transação sobre o fundo do direito transindividual, deveria a homologação judicial ser considerada requisito de eficácia do acordo?

No ponto, são sempre oportunos os ensinamentos de José Carlos Barbosa Moreira acerca dos riscos de se importar acriticamente técnicas estrangeiras, sem que se leve em consideração os aspectos estruturais de cada ordenamento ${ }^{76}$.

Parece-nos que, afora as distinções entre os dois sistemas em relação à legitimação, a coisa julgada, e o sofisticado e vigilante sistema de representatividade adequada, a compreensão de que homologação judicial seria necessária para se atribuir eficácia ao compromisso de ajustamento de conduta, quando versar sobre direitos indisponíveistransacionáveis, certamente retiraria a autonomia dos legitimados políticos ao seu

\footnotetext{
${ }^{75}$ MANCUSO, Rodolfo de Camargo. Interesses difusos: conceito e legitimação para agir. $6^{a}$ Ed. São Paulo: RT, 2004, p. 94.

${ }^{76}$ BARBOSA MOREIRA. O processo norte-americano e a sua influência, Parte Geral, Especial e a influência do processo penal norte-americano. In: Temas de Direito Processual, $8^{a}$ série. São Paulo, Saraiva, 2004 , p. 223.
} 
Revista Eletrônica de Direito Processual - REDP.

Rio de Janeiro. Ano 12. Volume 19. Número 2. Maio a Agosto de 2018

Periódico Quadrimestral da Pós-Graduação Stricto Sensu em Direito Processual da UERJ

Patrono: José Carlos Barbosa Moreira (in mem.). ISSN 1982-7636. pp. 118-148

www.redp.uerj.br

oferecimento, além de ir de encontro à tendência universal da desjudicialização de conflitos $^{77}$.

Contudo, aqui, temos que fazer uma distinção entre as instituições públicas e privadas. Quando uma instituição pública propõe o TAC ou a mediação, no âmbito extrajudicial, e o acordo é alcançado, a homologação judicial não é uma conditio sine qua non, ou seja, o acordo pode produzir seus efeitos desde logo, na medida em que o art. 32, § $3^{\circ}$ é regra específica se comparado ao art. $3^{\circ}, \S 2^{\circ}$, ambos da Lei $n^{\circ} 13.140 / 2015$.

Contudo, se o acordo é fruto de conciliação ou mediação em procedimento extrajudicial instaurado por instituição privada (associação de classe, por exemplo), a eficácia do acordo será sempre subordinada à homologação judicial, aplicando-se, neste caso, a regra geral do referido art. $3^{\circ} \S 2^{\circ}$.

Não custa lembrar, por fim, que se o acordo se der no curso de ação coletiva a homologação judicial será sempre necessária art. 334, § 11, 515, II, e 487, III, "b", todos do (PC), ainda que venha a envolver sujeito estranho ao processo ou versar sobre relação jurídica que não tenha sido deduzida em juízo (art. 515, § $2^{\circ}$ ).

$\mathrm{E}$, aqui, ponderamos que não se trata de uma atividade meramente homologatória. Sustentamos que o magistrado tem discricionariedade para não homologar o acordo, caso entenda que se trata de um direito indisponível não transacionável.

Nesse caso, ele proferirá decisão interlocutória recusando homologação (art. 334, § 11, a contrario sensu). O grande problema aqui é que essa hipótese não está, em princípio, prevista no art. 1.015 do CPC, o que nos levaria, numa primeira leitura, à conclusão de que tal ato do juiz seria irrecorrível, ao menos naquele momento. Poderiam as partes, futuramente, por ocasião da sentença, apelar e trazer essa questão nas razões ou nas contrarrazoes do apelo, nos exatos termos do art. 1.009, $\S 1^{\circ}$.

Contudo, pensamos nós, que se na decisão o juiz recusar a homologação sob o argumento de que o direito não admite autocomposição, isso equivale a uma decisão interlocutória de mérito e, nessa hipótese, a via do agravo de instrumento se mostra cabível nos exatos termos do art. 1.015, II (decisão sobre o mérito).

Por outro lado, se a recusa da homologação se prende a falta de um requisito formal, como por exemplo a ausência de assistência de advogado, ou mesmo ausência de

\footnotetext{
${ }^{77}$ PINHO, Humberto Dalla Bernardina de. VIDAL, Ludmilla Camacho Duarte. Primeiras reflexões sobre os impactos do novo CPC e da lei de mediação no compromisso de ajustamento de conduta, in Revista de Processo, vol. 256, ano 41, jun/2016, Revista dos Tribunais: São Paulo, p. 405
} 
Revista Eletrônica de Direito Processual - REDP.

Rio de Janeiro. Ano 12. Volume 19. Número 2. Maio a Agosto de 2018

Periódico Quadrimestral da Pós-Graduação Stricto Sensu em Direito Processual da UERJ

Patrono: José Carlos Barbosa Moreira (in mem.). ISSN 1982-7636. pp. 118-148

www.redp.uerj.br

representação ou assistência no caso do incapaz, a decisão resta não agravável, podendo ser atacada, apenas, nos restritos limites dos embargos de declaração, na forma do art. 1.022 .

\section{Considerações finais}

Dentro de um movimento global de estímulo a mecanismos adequados de resolução de conflitos, o Código de Processo Civil de 2015 e o Marco Legal da Mediação trazem significativos avanços para o sistema consensual de pacificação de conflitos na seara coletiva, vez que aumentam o objeto passível de negociações, atribuindo maior autonomia aos entes legitimados a firmar o compromisso de ajustamento de conduta.

Além do incremento dessas técnicas, as inovações normativas trazem também a necessidade de uma sistematização operacional. De que forma podemos nos valer do permissivo legal e aplicar as estratégias emergidas em um amplo procedimento dialógico, que seja adequado aos interesses metaindividuais?

Primeiramente, são imprescindíveis mecanismos de controle aos "novos ajustes". Nada obriga, contudo, que seja realizado pelo Poder Judiciário, já que a homologação judicial é desnecessária ante a eficácia de título executivo extrajudicial por força de lei, sendo o autor um ente público.

A segunda ideia vem como decorrência desses dois fatores, a exigência de maior controle e a prescindibilidade que ele ocorra em juízo. Como inexistem limites prefixados, parece desejável a submissão do TAC às instâncias deliberativas do seu proponente, recomendando-se normatização interna sobre a nova prática, o que, no caso do Ministério Público, foi, de certo modo, alcançado com a edição da Resolução n ${ }^{\circ}$ 179/2017 pelo Conselho Nacional do Ministério Público.

Por último, não se pode perder de vista que as técnicas da mediação e da conciliação exigem a imersão em um profundo processo discursivo, em que os resultados potenciais devem atender aos interesses transindividuais debatidos, de forma democrática e cooperativa. 
Revista Eletrônica de Direito Processual - REDP.

Rio de Janeiro. Ano 12. Volume 19. Número 2. Maio a Agosto de 2018

Periódico Quadrimestral da Pós-Graduação Stricto Sensu em Direito Processual da UERJ

Patrono: José Carlos Barbosa Moreira (in mem.). ISSN 1982-7636. pp. 118-148

www.redp.uerj.br

Nesse contexto, o êxito da prática consensual nesses conflitos complexos deve se valer da composição plural da sociedade ${ }^{78}$, não só dos órgãos colegitimados, como também de entidades como amicus curiae.

Uma alternativa interessante, sobretudo na parte das obras de grande envergadura e que possam trazer ameaças ao meio ambiente ou ao direito de uma coletividade, é a figura dos Dispute Boards, instituto largamente difundido no Direito norte-americano e que começa a ser mais estudado no Brasil. Interessante observar que houve um grande interesse por essa figura na I Jornada de Prevenção de Conflitos levada a cabo pelo STJ, sob a presidência do Eminente Min. Luis Felipe Salomão, e que levou à edição de alguns Enunciados ${ }^{79}$.

Nesse sentido, parece que o direito brasileiro vem evoluindo de modo a viabilizar uma instância de troca de ideias, com espaço para manifestações de todos os players, assegurando, ainda, que os rumos decididos devem levar em consideração, no maior grau possível, todos os interesses legitimamente expostos.

Nossa sociedade já atingiu um nível organizacional mínimo de modo a oferecer o tecido social necessário para que questões fundamentais sejam geridas, se proporcionada a participação dos interessados e de terceiros que possam auxiliar o legitimado na tomada da melhor decisão para o caso. Evita-se, assim, sobretudo, um provimento que por mais que seja bem-intencionado, acarrete consequências indesejáveis ou não se mostre eficaz no caso concreto.

Eis o desafio dos operadores do Direito nessa quadra da evolução legislativa brasileira: alinhar convenções materiais e processuais, direitos indisponíveis, mas transacionáveis, e garantir a criação de um locus adequado ao diálogo e que viabilize uma medida consensual, quando possível, e impositiva nas demais hipóteses, mas sempre

\footnotetext{
${ }^{78}$ PINHO, Humberto Dalla Bernardina de. PAUMGARTTEN, Michele Pedrosa. Os Desafios para a Integração entre o Sistema Jurisdicional e a Mediação a Partir do Novo Código de Processo Civil. Quais as Perspectivas para a Justiça Brasileira? In: REZENDE, Diogo. PELAJO, Samantha. PANTOJA, Fernanda (org.). A Mediação no Novo Código de Processo Civil. Rio de Janeiro: Forense, 2015, p. 11.

${ }^{79}$ Sobre a figura do Dispute Boards, foram aprovados 3 Enunciados no I Forum de Prevenção e Solução Extrajudicial de Conflitos. Ressaltamos, aqui, o Enunciado $\mathrm{n}^{\circ}$ 76: As decisões proferidas por um Comitê de Resolução de Disputas (Dispute Board), quando os contratantes tiverem acordado pela sua adoção obrigatória, vinculam as partes ao seu cumprimento até que o Poder Judiciário ou o juízo arbitral competente emitam nova decisão ou a confirmem, caso venham a ser provocados pela parte inconformada. Enunciados aprovados na I JORNADA "PREVENÇÃO E SOLUÇÃO EXTRAJUDICIAL DE LITÍGIOS", realizada em Brasília, nos dias 22 e 23 de agosto de 2016, disponíveis em http://www.cjf.jus.br/cjf/.
} 
assegurando o direito à manifestação de todos os interessados e sob a supervisão judicial, quando exigido por lei.

\section{REFERÊNCIAS BIBLIOGRÁFICAS:}

ALMEIDA, Diogo Assumpção Rezende de. Das Convenções Processuais no Processo Civil. Tese de Doutoramento. Universidade do Estado do Rio de Janeiro - UERJ, Rio de Janeiro, 2014.

ALMON, Matthew. Cadillac-Size Legal Fees" and "Chevrolet-Type Results": Settlement Scrutiny in Re Electronic Data Systems Corp. “Erisa” Litigation, 80 Tul. L. Rev. 2007. Accesso through Westlaw. 22nd Jan 2018.

BARBOSA MOREIRA, José Carlos. Convenção das partes sobre matéria processual. In: Temas de Direito Processual. $3^{a}$ série. São Paulo: Saraiva, 1984.

BARBOSA MOREIRA. O processo norte-americano e a sua influência, Parte Geral, Especial e a influência do processo penal norte-americano. In: Temas de Direito Processual, 8a série. São Paulo, Saraiva, 2004.

BEDAQUE, José Roberto dos Santos. Tutela cautelar e tutela antecipada: tutelas sumárias e de urgência (tentativa de sistematização). 4. ed. São Paulo: Malheiros, 2006.

CARVAlHO FILHO, José dos Santos. Ação Civil Pública: Comentários por Artigo. $3^{\mathrm{a}}$ Ed., Rio de Janeiro: Lumen Juris, 2001.

CUNHA, Leonardo Carneiro. Negócios Jurídicos Processuais no Direito Brasileiro. Disponível na internet. https://www.academia.edu/10270224. Acesso em 17 de abril de 2015.

DIDIER JR, Fredie. BOMFIM, Daniela. Colaboração premiada (Lei n. 12.850/2013): natureza jurídica e controle da validade por demanda autônoma - um diálogo com o Direito Processual

Civil, https://www.academia.edu/25608182/Colabora\%C3\%A7\%C3\%A3o_premiada_Lei_n._ 12.850_2013_natureza_jur\%C3\%ADdica_e_controle_da_validade_por_demanda_aut\% C3\%B4noma_um_di\%C3\%A1logo_com_o_Direito_Processual_Civil, acesso em 10 de julho de 2016. 
Revista Eletrônica de Direito Processual - REDP.

Rio de Janeiro. Ano 12. Volume 19. Número 2. Maio a Agosto de 2018

Periódico Quadrimestral da Pós-Graduação Stricto Sensu em Direito Processual da UERJ

Patrono: José Carlos Barbosa Moreira (in mem.). ISSN 1982-7636. pp. 118-148

www.redp.uerj.br

DOLE Jr., Richard F. The Settlement of Class Actions for Damages. 71 Colum. L. Rev. 971.

EISENBERT, Theodore. MILLER, Geoffrey P. Attorney Fees in Class Action

Settlements: An Empirical Study. Journal of Empirical Legal Studies Volume 1, Issue 1, 27-78, March 2004. Electronic copy available at: htttp://scholarship.law.cornell.edu/facpub/356/, access in November 2017.

ERICHSON, Howard M. The Problem of Settlement Class Action. 82 Geo. Wash. L. Rev. 951. Access through Westlaw in Jan $9^{\text {th }} 2018$.

FISS, O.M. Against Settlement, 93 Yale Law Journal 1073-90, May 1984.

FISS, O.M. The Class Action Rule, 78 Notre Dame Law Review, 1419 (2003).

FISS, O.M. The political theory of the class action. Washington and Lee Law Review vol. 53 (1996).

FITZPATRICK, Brian T. An Empirical Study of Class Action Settlements and Their Fee Awards. 7 Journal of Empirical Legal Studies (forthcoming 2010). Electronic copy available at: http://ssrn.com/abstract=1442108, access in November 2017, p. 9.

GIDI, Antonio. A Class Action como instrumento de tutela coletiva de direitos. São Paulo: Revista dos Tribunais, 2007.

GIDI, Antonio. Class action in Brazil - a model for civil law countries. The American Journal of Comparative Law, v. 51, n. 2, 2003.

GRECO, Leonardo. Instituições de Processo Civil - Introdução ao Direito Processual Civil. vol. 1, $5^{\mathrm{a}}$ ed, Rio de Janeiro: Forense, 2015.

GRECO, Leonardo. O juiz pode ser sujeito de um negócio processual? Palestra proferida no Seminário "Negócios Processuais no Novo CPC" promovida pela Associação dos Advogados de São Paulo/SP - AASP, em 06 de março de 2015.

KLONOFF, Robert. Class Actions and Other Multi-Party Litigation in a Nutshell. West Academic, 2017. Kindle's edition.

MACÊDO, Lucas Buril de; PEIXOTO, Ravi de Medeiros. Negócio processual acerca da distribuição do ônus da prova. In Revista de Processo, vol. 241/2015, p. 463-487, $\operatorname{mar} / 2015$.

MACEY, Jonathan R. MILLER, Geoffrey P. Judicial Review of Class Action Settlements, 1 J. Legal Analysis 167. Access through Westlaw. Jan 8th 2018. 
Revista Eletrônica de Direito Processual - REDP.

Rio de Janeiro. Ano 12. Volume 19. Número 2. Maio a Agosto de 2018

Periódico Quadrimestral da Pós-Graduação Stricto Sensu em Direito Processual da UERJ

Patrono: José Carlos Barbosa Moreira (in mem.). ISSN 1982-7636. pp. 118-148

www.redp.uerj.br

MANCUSO, Rodolfo de Camargo. Interesses difusos: conceito e legitimação para agir. $6^{\mathbf{a}}$

Ed. São Paulo: Ed. RT, 2004.

MARTEL, Letícia de Campos Velho. Direitos fundamentais indisponíveis: limites $e$ padrões do consentimento para a autolimitação do direito à vida. Tese de Doutorado. Uerj, 2010. Disponível em: http://works.bepress.com/leticia_martel/.

NERY JR., Nelson. O compromisso de ajustamento de conduta como transação hibrida e a problemática teorização da passagem do exercício do poder público para tentativa de ajuste no âmbito privado. In: A Ação Civil Pública após 25 anos. MILARÉ, Édis (coord.), São Paulo: Revista dos Tribunais, 2010.

NERY, Ana Luiza de Andrade. Compromisso de Ajustamento de Conduta. Teoria e Análise de casos práticos. $2^{\mathrm{a}}$ Ed. São Paulo: Revista dos Tribunais, 2012.

OQUENDO, Angel. State Settlements in Vindication of Societal Rights. Original paper kindly provided by the author in January 2018.

PINHO, Humberto Dalla Bernardina de; FARIAS, Bianca Oliveira de. Apontamentos sobre o compromisso de ajustamento de conduta na Lei de Improbidade Administrativa e no Projeto de Lei da Ação Civil Pública. In: Temas de Improbidade Administrativa. ${ }^{\text {st }}$ edition, Rio de Janeiro: Lumen Juris, 2010, v.1.

PINHO, Humberto Dalla Bernardina de. O Marco Legal da Mediação no Brasil: Comentários à Lei n 13.140/15.1 ed. São Paulo: Atlas, 2015.

PINHO, Humberto Dalla Bernardina de. PAUMGARTTEN, Michele Pedrosa. Os Desafios para a Integração entre o Sistema Jurisdicional e a Mediação a Partir do Novo Código de Processo Civil. Quais as Perspectivas para a Justiça Brasileira? In: REZENDE, Diogo. PELAJO, Samantha. PANTOJA, Fernanda (org.). A Mediação no Novo Código de Processo Civil. Rio de Janeiro: Forense, 2015.

PINHO, Humberto Dalla Bernardina de. The Undertaking of Adjustment of Conduct in Brazilian Collective Procedural Law. Connecticut Journal of International Law. Vol, 27: 346, Spring 2012.

PINHO, Humberto Dalla Bernardina de. VIDAL, Ludmilla Camacho Duarte. Primeiras reflexões sobre os impactos do novo CPC e da lei de mediação no compromisso de ajustamento de conduta, In Revista de Processo, vol. 256, ano 41, jun/2016, Revista dos Tribunais: São Paulo, pp. 371/411. 
Revista Eletrônica de Direito Processual - REDP.

Rio de Janeiro. Ano 12. Volume 19. Número 2. Maio a Agosto de 2018

Periódico Quadrimestral da Pós-Graduação Stricto Sensu em Direito Processual da UERJ

Patrono: José Carlos Barbosa Moreira (in mem.). ISSN 1982-7636. pp. 118-148

www.redp.uerj.br

PINHO. Humberto Dalla Bernardina de. MELLO PORTO, José Roberto Sotero de.

Colaboração premiada: um negócio jurídico processual? In Revista Magister de Direito

Penal e Processual Penal, vol. 73, Ago/Set 2016, Magister: Porto Alegre.

PIZZOL, Patrícia Miranda. Liquidação nas ações coletivas. São Paulo: Lejus, 1998.

RATNER, Morris A. Class Conflicts, 92 Wash. L. Rev. 785. Access through Westlaw. Jan 6th 2018.

ROQUE, Andre Vasconcelos. Class actions - ações coletivas nos Estados Unidos: o que podemos aprender com eles? Salvador: Juspodivm, 2013.

RUBENSTEIN, William B. Emerging Issues in Class Action Law. 53 UCLA L. Rev. 1435. Access through Westlaw. Jan, 18th, 2018.

SALLES, Carlos Alberto de. Arbitragem em Contratos Administrativos. Rio de Janeiro: Forense, 2012.

SMITH, Thomas. WILLIAMS Elizabeth. Court approval of class action settlement, 6 Cyc. of Federal Proc. $\$ 23: 42$ (3d ed.). Access through Westlaw. Jan $5^{\text {th }}, 2018$.

TAKAHASHI, Bruno. Desequilíbrio de poder e conciliação, Brasília: Gazeta Jurídica, 2016.

TARTUCE, Fernanda. Igualdade e Vulnerabilidade no Processo Civil. São Paulo: Método, 2012.

VENTURI, Elton. Transação de Direitos Indisponíveis? In Revista de Processo, vol. 251, São Paulo: Revista dos Tribunais, jan / 2016. 